\title{
Vascular
}

\section{Incidence of Major Complication Following Embolo- Sclerotherapy for Upper and Lower Extremity Vascular Malformations}

\begin{tabular}{|c|c|}
\hline Journal: & Vascular \\
\hline Manuscript ID & VASCULAR-03-20-OA-1741.R2 \\
\hline Manuscript Type: & Original Article \\
\hline $\begin{array}{r}\text { Date Submitted by the } \\
\text { Author: }\end{array}$ & 24-May-2020 \\
\hline Complete List of Authors: & $\begin{array}{l}\text { Lim, Chung Sim; Royal Free London NHS Foundation Trust, Vascular } \\
\text { Surgery } \\
\text { Evans, Nicholas; Royal Free London NHS Foundation Trust } \\
\text { Kaur, Ishapreet; Royal Free London NHS Foundation Trust } \\
\text { Papadopoulou, Anthie; Royal Free London NHS Foundation Trust } \\
\text { Khalifa, Mohamed; Royal Free London NHS Foundation Trust } \\
\text { Tsui, Janice; Royal Free London NHS Foundation Trust } \\
\text { Hamilton, George; Royal Free London NHS Foundation Trust } \\
\text { Brookes, Jocelyn; Royal Free London NHS Foundation Trust }\end{array}$ \\
\hline Keywords: & $\begin{array}{l}\text { Vascular malformation, Arteriovenous malformation, Embolo- } \\
\text { sclerotherapy, Sclerotherapy, Embolization, Complications }\end{array}$ \\
\hline
\end{tabular}

\section{SCHOLARONE \\ Manuscripts}




\section{Reduced-Incidence of Major Complication Rates-Followingfrom Embolo-Sclerotherapy for $\theta$ f Uper and Lower Extremity Vascular Malformations}

Chung Sim Lim ${ }^{1,2,3,5}$, Nicholas Evans ${ }^{1,5}$, Ishapreet Kaur ${ }^{1}$, Anthie Papadopoulou ${ }^{1,4}$, Mohamed Khalifa $^{1,4}$, Janice Tsui ${ }^{1,2,3}$, George Hamilton ${ }^{1,2}$, Jocelyn Brookes ${ }^{1,4}$

1. Royal Free Vascular Malformation Service, Department of Vascular Surgery, Royal Free London NHS Foundation Trust, London, United Kingdom, London

2. Department of Surgical Biotechnology, Division of Surgery \& Interventional Science, Faculty of Medical Sciences, University College London, UK

3. NIHR UCLH Biomedical Research Centres, London, UK

4. Department of Interventional Radiology, Royal Free London NHS Foundation Trust, London, UK

5. Joint first author

Short title: Vascular Malformation Embolo-Sclerotherapy

\section{Corresponding author}

Mr Chung Sim Lim

Department of Vascular Surgery, Royal Free Hospital, Pond Street, London NW3 2QG, United Kingdom

Tel no: +44 (0) 207794 0500; Fax No: +44 (0) 2074726278

E-mail: chunglim@nhs.net 


\begin{abstract}
Purpose

The current literature on the major complications of embolo-sclerotherapy (EST) of upper and lower extremity vascular malformations (VMs) is scarce. Evaluating and understanding the rates and types of potential major complications of EST of VMs help treatment planning and informed consent. Therefore, this study reviewed major complications following EST of all upper and lower extremity VMs in a single single specialized multidisciplinary VM center over a 5-year period.

Methods

All patients with VMs underwent multidisciplinary directed intervention. Demographic, procedural, follow-up and complication data were collected prospectively in a dedicated database, and reviewed retrospectively. Major complications for upper and lower extremity VMs from January 1, 2013 to December 31, 2017 were analyzed. All ESTs of high-flow vascular malformations (HFVMs) were performed under selective catheter angiography and direct injection, but low-flow vascular malformations (LFVM) with direct injection only. Major complications were defined as any tissue or functional damage caused by direct injection, distal embolization or tissue reaction.

Results

Seventy patients (median age of 25 years; 44 males and 26 females) had 150 EST procedures for upper extremity VM. Of these, 28 patients had EST for HFVM and 42 patients for LFVM; total 78 and 72 procedures, respectively. A total of 107 patients (median age of 26 years; 42 males and 65 females) had 160 EST interventions for lower extremity VMs. Of these, 18 patients had EST for HFVM and 89 patients for LFVM; total of 30 and 130 procedures, respectively. The
\end{abstract}


overall major complication rates following EST of upper and lower extremity VMs were 14.3\% and $4.7 \%$, respectively $(\mathrm{P}=0.030)$. In the upper extremity HFVM group, major complications from EST occurred in 5 patients; 3 ischemic fingers requiring amputation and 2 skin ulcerations. Meanwhile, in the upper extremity LFVM group, major complications occurred in 5 patients; 1 median nerve injury requiring nerve grafting and hand therapy, 1 hand contracture requiring tendon release, and 3 skin ulcerations. There was only one major complication which was cellulitis in the lower extremity HFVM group. In the lower extremity LFVM group, major complications occurred in 4 patients; 2 skin ulcerations, 1 cellulitis and 1 deep vein thrombosis.

\section{Conclusions}

EST is relatively safe for upper and lower extremity VMs in a high-volume experienced center where our major complication rates were $14.3 \%$ and $4.7 \%$, respectively which compare favorably or similar to those reported in most recent literature. These outcomes will direct treatment strategies to avoid local and systemic toxic complications in the upper and and lower extremity, for both HFVM and LFVM, and to improve informed consent.

\section{Key words}

Vascular malformation, arteriovenous malformation, embolo-sclerotherapy, sclerotherapy, embolization, complications. 


\section{Introduction}

Embolo-sclerotherapy (EST) is an important interventional treatment for vascular malformations (VMs) including those in the upper and lower extremities ${ }^{1-5}$. Despite being minimally invasive, EST for upper and lower extremity VMs carries significant risk of major complications including ischemia, infarction, amputation, nerve injury, contracture, and ulceration ${ }^{13-9}$. For example, major complication rates of as high as $61 \%$ and $24 \%$ for hand and foot arteriovenous malformation treatments, respectively were most recently reported ${ }^{34}$. A recent study reported a complication rate of $12.3 \%$ from sclerotherapy of intramuscular venous malformation of the upper and lower extremity9 ${ }^{9}$ Post-operative death including from pulmonary embolism following EST of peripheral VM has also recently been reported ${ }^{10}$.

Despite improved care in specialist centers, up-to-date estimates of complication risk for audit and informed consent are scarce; recent literature focuses on high-flow vascular malformations (HFVM) with a paucity of data for low-flow vascular malformations (LFVM). Therefore, this study aimed to review major complications following EST of all upper and lower extremity VM in our specialized multidisciplinary center for vascular anomalies over a 5-year period. Improving our existing understanding and knowledge on major complications following EST, particularly when the information in the literature on this was scarce, would help direct treatment strategies to avoid local and systemic toxic complications in the upper and and lower extremity, for both HFVM and LFVM, and to aid informed consent.

\section{Methods}


This is a retrospective audit study of a prospectively collected departmental database with no patient identifiable data used; that were carried for service improvement as part of the clinical governance of the department,, hence did not require institutional review board approval and informed consent.

\section{Embolo-sclerotherapy (EST)}

All patients with non-central nervous system VM treated in our hospital underwent multidisciplinary team (including vascular surgeons, interventional radiologists and clinical nurse specialist) review directed intervention. Our center received tertiary referrals of peripheral vascular anomalies from around the country. All the clinicians in the multidisciplinary team who performed the EST in this study were consultant interventional radiologists and consultant

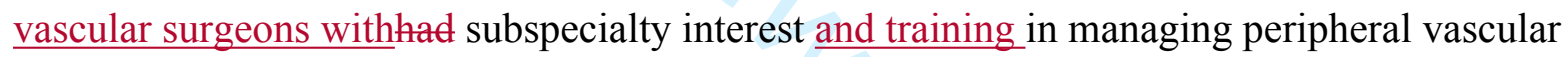
anomalies. EST was our mainstay interventional treatment for patients with rapidly growing and/or significantly symptomatic VMs which included pain and discomfort, disfiguration, swelling, pressure effect, ulceration, bleeding, localized intravascular coagulopathy, and cardiac failure. Patients with asymptomatic or minimally symptomatic VMs which were stable were treated with conservative treatment.

Clinically, we classified the VM into HFVM when it is an arteriovenous malformation; whereas LFVM when it is not an arteriovenous malformation such as venous, lymphatic, capillary, and a combination of these. Pre-operative cross-sectional images i.e. computed tomography (CT) and/or magnetic resonance imaging were performed on all patients to aid planning of the EST. All ESTs were performed under general anaesthetics to limit patient movement and anxiety. All 
ESTs of HFVM were performed under selective catheter angiography and direct injection, but LFVM with direct injection only. All ESTs during this study were carried out under fluoroscopy guidance with digital subtraction angiography performed to confirm the accurate position of the catheter and/or needles, and to assess the flow; either in a vascular hybrid theatre with a floor mounted C-arm, or standard operating theatre with a mobile C-arm. Ultrasound was also used in some cases, but not cone beam CT. ESTs were performed either with foam sclerosants (sodium tetradecyl sulphate $3 \%$ or polidocanol; mixed with air in either 1:4 or 3:8 ratio), ethanol, embolization coils, a few other substances such as Onyx, and a combination of them (Table 1), and the choice of agents used was determined based on the operator's discretion. The majority of the ESTs were carried out as day cases, and followed up in the out-patient clinic around 6 to 12 weeks post-operatively.

\title{
$\underline{\text { Data collection }}$
}

All patients with HFVM and LFVM of upper and lower extremities, who underwent EST in our center from 1 January 2013 to 31 December 2017 were identified. Demographic, anatomical, procedural, treatment outcome, complication, and follow-up data collected in a prospective database were analyzed. Major complications were defined as any tissue or functional damage caused by direct injection, distal embolization or tissue reaction. The major complications in the study were determined by our multidisciplinary team described above.

\author{
$\underline{\text { Statistical analysis }}$ \\ Data was collected and analyzed using Microsoft Office Excel (Redmond, Washington, USA) \\ and GraphPad Prism 7.04 (GraphPad Sorftware, San Diego CA). Data was presented as median
}


and range. Proportional data was presented in percentage. Differences in the rates of major complications between subgroups were analyzed using Chi-square and Fisher's exact tests. $\underline{\mathrm{P}<0.05 \text { was considered significant. }}$

\section{Results}

Upper extremity vascular malformations

\section{Patients}

During the study period, 70 patients had a total of 150 EST procedures for upper extremity VMs with a median age of 25 years (range $1-73$ years); $44(63 \%)$ males and $26(37 \%)$ females. Of these, $28(40 \%)$ had EST for HFVM and 42 (60\%) for LFVM; total of 78 and 72 procedures respectively. All the LFVM in the upper extremity were venous except one lymphatic malformation. Table 1 summarizes the embolizing agents used for all the EST procedures for upper and lower VM. Meanwhile, table 2 summarizes the anatomical distribution of the VMs in the upper and lower extremities. EST involving the hand were done in 21 patients (75\%) or 64 procedures (82\%) for HFVM, and 15 patients (35\%) or 29 procedures $(40 \%)$ for LFVM.

\section{Major complications}

In total, ten patients (14.3\%) sustained major complications from EST procedures of upper extremity VMs over 5 years (6.7\% of total procedures). In the upper extremity HFVM group, major complications from EST occurred in 5 patients (17.9\%) or 6.4\% of total procedures. Meanwhile, in the upper extremity LFVM group, major complications occurred in 5 patients $(11.9 \%)$ or $6.9 \%$ of total procedures. The major complications for the EST of the upper extremity VMs in the study were summarized in Table $\underline{3} z$. Figure 1 shows an angiogram and photographs 
of ischemic and gangrenous right distal index and little finger requiring amputation in a patient who had EST of HFVM of the hand. Figure 2 shows photographs skin ulceration of the dorsum of the right hand of a patient who had EST of LFVM of the hand. Significant differences in the rate of major complications were observed when anatomical distributions of the upper extremity

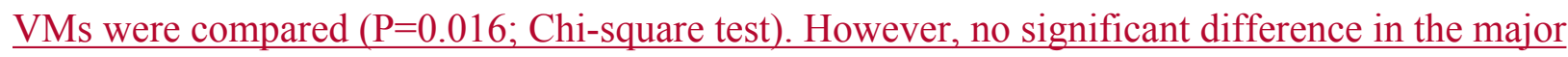
complication rates was found between EST of HFVM and LFVM of the upper extremities $\underline{(\mathrm{P}=0.507 \text {; Fisher's exact test }) .}$

All skin ulcerations resolved with medical treatment only without significant long-term disability. However, the nerve injury, hand contracture and amputations carried some degrees of long-term functional disability.

All patients with skin ulceration and cellulitis recovered with medical treatment only. The patient who developed muscular contracture subsequently underwent tendon release surgery with good overall functional outcome eventually. Meanwhile, the patient who suffered median nerve injury subsequently underwent nerve grafting by the plastic surgeons, and required on-going hand therapy and neurological follow-up. The three patients, all underwent EST for HFVM of the hand, developed ischemic and gangrenous fingers secondary to distal embolization with or without some degree of steal syndrome from the HFVM, and required amputation.

$\underline{\text { Lower extremity vascular malformations }}$

Patients

A total of 107 patients had 160 ESTs with the median age of 26 years (range $8-70$ years); 42 
All the major complications of the lower extremity EST resolved with medical treatment without significant long-term physical or functional disability although the single DVT case required a period of anticoagulation only. 


\section{Discussion}

This study reported a wide range of major complications from EST of upper and lower extremity VMs including some with long term implications. There was significantly higher rate of major complications found in the EST of the upper than the lower extremity VMs. The majority of major complications reported in this study were due to local toxicity of the EST agents, particularly in those treated for LFVM, causing skin ulceration, cellulitis, hand contracture, and median nerve injury causing wrist drop. IAll patients with skin ulceration and cellulitis recovered with medical treatment only. The patient who developed muscular contracture subsequently underwent tendon release surgery with good overall functional outcome eventually. Meanwhile, the patient who suffered median nerve injury subsequently underwent nerve grafting by the plastic surgeons, and required on-going hand therapy and neurological follow-up. One patient with LFVM of the lower extremity developed DVT and required a period of anti-coagulation only. Finally, three patients, all underwent EST for HFVM of the hand, developed ischemic and gangrenous fingers secondary to distal embolization with or without some degree of steat syndrome from the HFVM, and required amputation. Despite not proven, it is worth pointing out that our major complications from EST of the upper extremity HFVM and LFVM appeared to be

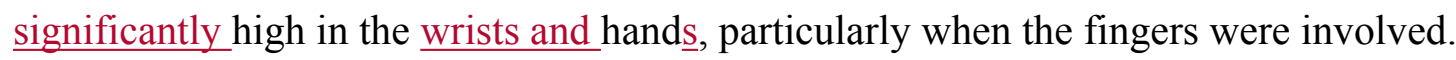

Therefore, performing EST on any VM that involves the hand and fingerswrists and hands must be regarded as potentially high risk and should not be taken lightly, with all patients counseled including with the potential major complications thoroughly explained. Furthermore, upper and lower extremities vary in terms of their anatomy such as vascularity and distribution of the nerves, and functions, hence they are likely to have differences in their complication rates and profiles even though the EST technique used is the same. Interestingly, there were no significant 


\section{differences found in the major complication rates from EST of HFVM and LFVM within the}

upper and lower extremity groups in this study although the sample size of this study might be too small to demonstrate this.

Understanding the major complication rates of EST for VMs is important in helping clinicians and patients make decisions with informed consent. Although EST is widely used to treat VMs of the upper and lower extremity VMs, there are only a few studies reporting on the complication rates in recent literature. Vogelzang et al. retrospectively evaluated endovascular therapy, principally with ethanol embolization, for 46 patients with VMs including nine involving the upper extremity, 31 in the lower extremity and 6 in the trunk, in a single center; with the overall complication rate of $24 \%{ }^{5}$. Park et al. reported a complication rate of $61 \%$ for ethanol EST in hand arteriovenous malformations (AVMs) in a retrospective study of 31 patients ${ }^{4}$. These complications included skin necrosis in 14 patients (45\%), bullae in 7 patients $(23 \%)$, joint stiffness or contracture in 6 patients $(19 \%)$, and transient nerve palsy in 4 patients $(13 \%)$; all of them resolved completely except in 2 patients who underwent amputation. In another retrospective study, a complication rate of $49 \%$ was reported in 41 patients who underwent EST with ethanol involving the hand; 17 patients with skin necrosis (including 1 who had autoamputation and 2 who underwent amputation) and 7 patients with transient neuropathic complications $^{8}$. Hyun et al. retrospectively reviewed 29 patients who had ethanol EST for foot AVMs, and reported major and minor complication rates of $24 \%$ and $52 \%$, respectively; skin necrosis being the most common for the latter ${ }^{3}$. More recently, Park et al. retrospectively reviewed 306 patients with body and extremity AVMs who were treated over 20 years, during which 913 endovascular therapies were performed ${ }^{11}$. The overall major and minor complication 
rates by number of procedure were $3.1 \%$ and $20.1 \%$, respectively. The most common complications reported included skin necrosis, bullae formation and nerve injury. A recent single center retrospective study of 81 patients reported a complication rates of $12.3 \%$ from sclerotherapy of upper and lower extremity intramuscular venous malformation. These complications included 1 case of major nerve injury, 6 cases of skin necrosis and ulceration, and 3 cases of superficial venous thrombosis ${ }^{9}$. Our complication rates in this study appeared to compare favorable or similar to those-_in the literature; likely as a result of experience bias i.e. performance by high skilled operators at a specialized center with high volume of cases, and as such may merit these cases being done by similar type of professionals. Furthermore, it is important to note that the anatomical distributions and types of VMs, and the definitions of complications as well as the classification of their severity varied among studies. Moreover, so far there is no agreed reporting guidelines or consensus on what are considered complications and their severity following EST of VM. Such reporting guidelines and consensus is clearly needed to compare clinical outcomes between studies.

It is important to stress that this study was not designed to evaluate if any particular EST agent of any concentration was safer than the others for upper and lower extremity VMs. Therefore, we could not draw any conclusion on or recommend which EST agent or combination of agents was associated with the lowest risk of major complications. Meanwhile, there is no high level of evidence in the literature to support the method of EST, and the choice and concentration of agents, hence experience and familiarity with techniques remains the most reliable determinants of clinical outcomes ${ }^{1012}$. For example, foam sclerotherapy with STS is often used to treat LFVM, whereas ethanol is used for both HFVM and LFVM ${ }^{13-15}$. The overall complication rate of ethanol 
sclerotherapy of AVM has been reported to be relatively high, ranging from $10 \%$ to $52 \%$; with the use of absolute ethanol to be associated with the highest complication rates 211 16-20. Therefore, diluted ethanol has been used to reduce complication rate and ethanol dose ${ }^{11}$. It is also

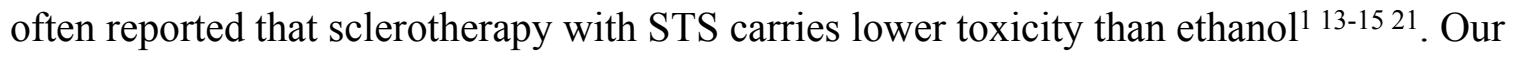
experience with foamed STS, which is our most commonly used EST agent including in this study, has been good in terms of clinical efficacy and safety, for both HFVM and LFVM. Therefore, our selective use of foamed STS over alcohol might have contributed to our relatively favorable major complication rates although further studies will be required to confirm this. It is also important to be aware that all EST agents can potentially cause local and systemic complications, hence they must always be used cautiously, appropriately and within their recommended indications. Staged approach of EST in some cases of extensive VM, might reduce the risks of complications and toxicity of the sclerosants. We also believe that other factors including our multidisciplinary management approach, improved classification and targeted treatment, increasing learning curve and clinical experience, and high volume of cases for EST of upper and lower extremity VMs performed in our center were also important $t^{61122}$.

Only simple statistical analyses were used and deemed sufficient to meet the aim of this study to report on the types and rates of major complications from EST of VM in the upper and lower extremities in our practice. Rigorous statistical analyses were considered but unlikely to provide additional clinical value in this study due to the relatively small number of major complications, highly heterogeneous groups of patients and lesions, and evaluation of the subgroups such as between HFVM and LFVM or upper and lower extremities, was not really comparing like with like. Future prospective studies with larger samples and longer follow-up should focus on 
assessing the potential factors that determine outcomes and complications including with multivariate analysis.

\section{Limitations}

There were several limitations in this study. Firstly, although our database was prospectively collected, the data was analyzed retrospectively, hence leading to potential biases. All major complications were identified and recorded prospectively in the database, hence likely to reduce the risk of potential selection bias. Secondly, despite being a high-volume tertiary center for vascular anomalies, statistical differences between the subgroups, hence the potential risk factors for major complications of EST in this study should be interpreted with caution due to our sample size was still not large enough to perform any meaningful detailed statistical analyses to compare between subgroups including EST agent types and detailed classification of the VM.the large heterogeneity of VMs. -Since VM is relatively uncommon, any larger sample size study will require a multi-center design including a registry. Thirdly, our definition of major complication might differ from those used in other similar studies in the literature. However, there was no one universally accepted definition of what should be considered as major complication following EST. Our major complications were identified by the multidisciplinary team including the vascular surgeons and interventional radiologists based on our clear definition. Finally, detailed information particularly as per the International Society for the Study of Vascular Anomalies (ISSVA) and Schobinger classification were not routinely collected hence not fully included in this study. However, we provided information such as the flow, predominant vessel type, anatomical location and patient demography which were often considered clinically relevant when planning for EST treatment strategy. Since only patients with 
rapidly growing and/or significantly symptomatic patients were offered EST, most if not all of the patients with HFVM treated in this study should be stage II to IV on Schobinger classification.

\section{Conclusions}

Current EST is relatively safe for upper and lower extremity VMs in a high-volume experienced center where our major complication rate of $14.3 \%$ and $4.7 \%$, respectively compare favorably or similar to those reported in most recent literature. This is possibly due to our multidisciplinary management approach, improved classification and targeted treatment, and high volume of cases. These outcomes will direct treatment strategies to avoid local and systemic toxic complications in the upper and and lower extremity, for both HFVM and LFVM, and to improve informed consent. Finally, an internationally agreed reporting guidelines or consensus is clearly needed to define complications following VM interventions including EST to allow meaningful comparison between studies.

\section{Disclosure of conflict of interest}

None

\section{References}

1. Lee BB, Baumgartner I, Berlien HP, Bianchini G, Burrows P, Do YS, et al. Consensus Document of the International Union of Angiology (IUA)-2013. Current concept on the management of arterio-venous management. Int Angiol 2013;32(1):9-36. 
2. Mulligan PR, Prajapati HJ, Martin LG, Patel TH. Vascular anomalies: classification, imaging characteristics and implications for interventional radiology treatment approaches. $\mathrm{Br} J$ Radiol 2014;87(1035):20130392.

3. Hyun D, Do YS, Park KB, Kim DI, Kim YW, Park HS, et al. Ethanol embolotherapy of foot arteriovenous malformations. J Vasc Surg 2013;58(6):1619-26.

4. Park HS, Do YS, Park KB, Kim DI, Kim YW, Kim MJ, et al. Ethanol embolotherapy of hand arteriovenous malformations. J Vasc Surg 2011;53(3):725-31.

5. Vogelzang RL, Atassi R, Vouche M, Resnick S, Salem R. Ethanol embolotherapy of vascular malformations: clinical outcomes at a single center. J Vasc Interv Radiol 2014;25(2):20613; quiz 14.

6. Markovic JN, Shortell C. Tips for contemporary management of congenital arteriovenous malformations. Vascular Disease Management 2017;14(6):E151-E53.

7. Lee KB, Kim DI, Oh SK, Do YS, Kim KH, Kim YW. Incidence of soft tissue injury and neuropathy after embolo/sclerotherapy for congenital vascular malformation. J Vasc Surg 2008;48(5):1286-91.

8. Park UJ, Do YS, Park KB, Park HS, Kim YW, Lee BB, et al. Treatment of arteriovenous malformations involving the hand. Ann Vasc Surg 2012;26(5):643-8. 
9. Bianchini G, Camilli D, Furgiuele S. Intramuscular Venous Malformations of the Upper and Lower Limbs: Indications and Outcomes of Sclerotherapy. Cardiovasc Intervent Radiol 2018;41(10):1505-12.

10. Nassiri N, Huntress LA, Simon M, Murphy S. An institution-wide algorithm for direct-stick embolization of peripheral venous malformations. J Vasc Surg Venous Lymphat Disord 2018;6(3):351-57.

11. Park KB, Do YS, Kim DI, Kim YW, Park HS, Shin SW, et al. Endovascular treatment results and risk factors for complications of body and extremity arteriovenous malformations. $J$ Vasc Surg 2019;69(4):1207-18.

12. Alomari A, Dubois J. Interventional management of vascular malformations. Tech Vasc Interv Radiol 2011;14(1):22-31.

13. Sierre S, Teplisky D, Lipsich J. Vascular malformations: an update on imaging and management. Arch Argent Pediatr 2016;114(2):167-76.

14. Muller-Wille R, Wildgruber M, Sadick M, Wohlgemuth WA. Vascular Anomalies (Part II): Interventional Therapy of Peripheral Vascular Malformations. Rofo 2018.

15. van der Vleuten CJ, Kater A, Wijnen MH, Schultze Kool LJ, Rovers MM. Effectiveness of sclerotherapy, surgery, and laser therapy in patients with venous malformations: a systematic review. Cardiovasc Intervent Radiol 2014;37(4):977-89. 
16. Yakes WF, Rossi P, Odink H. How I do it. Arteriovenous malformation management. Cardiovasc Intervent Radiol 1996;19(2):65-71.

17. Do YS, Park KB, Park HS, Cho SK, Shin SW, Moon JW, et al. Extremity arteriovenous malformations involving the bone: therapeutic outcomes of ethanol embolotherapy. $J$ Vasc Interv Radiol 2010;21(6):807-16.

18. Cho SK, Do YS, Shin SW, Kim DI, Kim YW, Park KB, et al. Arteriovenous malformations of the body and extremities: analysis of therapeutic outcomes and approaches according to a modified angiographic classification. J Endovasc Ther 2006;13(4):527-38.

19. Do YS, Yakes WF, Shin SW, Lee BB, Kim DI, Liu WC, et al. Ethanol embolization of arteriovenous malformations: interim results. Radiology 2005;235(2):674-82.

20. Shin BS, Do YS, Lee BB, Kim DI, Chung IS, Cho HS, et al. Multistage ethanol sclerotherapy of soft-tissue arteriovenous malformations: effect on pulmonary arterial pressure. Radiology 2005;235(3):1072-7.

21. Behravesh S, Yakes W, Gupta N, Naidu S, Chong BW, Khademhosseini A, et al. Venous malformations: clinical diagnosis and treatment. Cardiovasc Diagn Ther 2016;6(6):55769.

22. Lee BB, Do YS, Yakes W, Kim DI, Mattassi R, Hyon WS. Management of arteriovenous malformations: a multidisciplinary approach. J Vasc Surg 2004;39(3):590-600. 


\section{Tables}

Table 1. Embolo-sclerotherapy agents used for low-flow and high-flow vascular malformations in this study. STS: sodium tetradecyl sulphate.

\begin{tabular}{|c|c|c|c|c|}
\hline \multirow{3}{*}{$\begin{array}{c}\text { Embolo-sclerotherapy } \\
\text { agent }\end{array}$} & \multicolumn{4}{|c|}{ Number of procedure } \\
\hline & \multicolumn{2}{|c|}{ Upper Extremity } & \multicolumn{2}{|c|}{ Lower Extremity } \\
\hline & High-flow & Low-flow & High-flow & Low-flow \\
\hline Foamed STS $3 \%$ only & 31 & 61 & 20 & 101 \\
\hline $\begin{array}{c}\text { Foamed polidocanol 1\% } \\
\text { only }\end{array}$ & 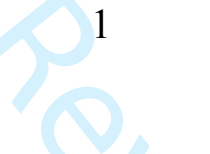 & 6 & 0 & 12 \\
\hline Ethanol only & 23 & 3 & 4 & 9 \\
\hline Coils only & 0 & 0 & 0 & 1 \\
\hline Foamed STS 3\% + Ethanol & 9 & 1 & 4 & 2 \\
\hline Foamed STS 3\% + Coils & 2 & 0 & 0 & 0 \\
\hline Ethanol + Coils & 4 & 0 & 1 & 0 \\
\hline Others & 8 & 1 & 1 & 5 \\
\hline Total & 78 & 72 & 30 & 130 \\
\hline
\end{tabular}


Table 2. Anatomical distribution of the vascular malformations treated with embolosclerotherapy in the upper and lower extremities.

\begin{tabular}{|l|l|}
\hline$\underline{\text { Anatomical location }}$ & $\underline{\text { Number of patients }}$ \\
\hline$\underline{\text { Upper extremities }}$ & $\underline{19}$ \\
$\underline{\text { Shoulder and upper arm }}$ & $\underline{17}$ \\
$\underline{\text { Elbow and forearm }}$ & $\underline{34}$ \\
\hline$\underline{\text { Wrist and hand }}$ & $\underline{27}$ \\
\hline$\underline{\text { Lower extremities }}$ & $\underline{50}$ \\
$\underline{\text { Buttock and thigh }}$ & $\underline{30}$ \\
\hline$\underline{\text { Knee and lower leg }}$ & $\underline{\text { Ankle and foot }}$ \\
\hline
\end{tabular}


Table $\underline{3} z$. Patients with major complications following embolo-sclerotherapy of upper extremity vascular malformations. EST: embolo-sclerotherapy, HFVM: high-flow vascular malformation, LFVM: low-flow vascular malformation, STS: sodium tetradecyl sulphate

\begin{tabular}{|c|c|c|c|c|c|c|}
\hline Patient & $\begin{array}{l}\text { Age } \\
\text { (years) } \\
\text { / gender }\end{array}$ & $\begin{array}{l}\text { Type of } \\
\text { vascular } \\
\text { malformation }\end{array}$ & Anatomy & Procedure & Complication & $\begin{array}{l}\text { Treatment } \\
\text { and outcome }\end{array}$ \\
\hline 1 & $\begin{array}{l}50 / \\
\text { female }\end{array}$ & HFVM & $\begin{array}{l}\text { Right } \\
\text { ring } \\
\text { finger }\end{array}$ & $\begin{array}{l}\text { Angiography } \\
\text { and direct } \\
\text { injection } \\
\text { EST ( } 0.5 \\
\text { ml of STS } \\
3 \% \text { foamed } \\
\text { with air) }\end{array}$ & $\begin{array}{l}\text { Ischaemia and } \\
\text { gangrene }\end{array}$ & $\begin{array}{l}\text { Amputation } \\
\text { of right ring } \\
\text { finger }\end{array}$ \\
\hline 2 & $\begin{array}{l}44 / \\
\text { female }\end{array}$ & HFVM & $\begin{array}{l}\text { Palm of } \\
\text { right } \\
\text { hand }\end{array}$ & $\begin{array}{l}\text { Angiography } \\
\text { and direct } \\
\text { injection } \\
\text { EST ( } 2 \mathrm{ml} \text { of } \\
\text { STS 3\% } \\
\text { foamed with } \\
\text { air) }\end{array}$ & $\begin{array}{l}\text { Ischaemia and } \\
\text { gangrene } \\
\text { (Figure 1) }\end{array}$ & $\begin{array}{l}\text { Amputation } \\
\text { of right distal } \\
\text { index and } \\
\text { little finger }\end{array}$ \\
\hline 3 & $69 /$ & HFVM & Left & Angiography & Ischaemia and & Amputation \\
\hline
\end{tabular}




\begin{tabular}{|c|c|c|c|c|c|c|}
\hline & female & & $\begin{array}{l}\text { index } \\
\text { finger }\end{array}$ & $\begin{array}{l}\text { and direct } \\
\text { injection } \\
\text { EST ( } 2 \mathrm{ml} \text { of } \\
\text { ethanol, and } \\
2 \mathrm{ml} \mathrm{STS} \mathrm{3 \%} \\
\text { foamed with } \\
\text { air) }\end{array}$ & gangrene & $\begin{array}{l}\text { of left index } \\
\text { finger }\end{array}$ \\
\hline 4 & $\begin{array}{l}37 / \\
\text { male }\end{array}$ & HFVM & $\begin{array}{l}\text { Right } \\
\text { thumb }\end{array}$ & $\begin{array}{l}\text { Angiography } \\
\text { and direct } \\
\text { injection } \\
\text { EST ( } 2 \mathrm{ml} \\
\text { STS 3\% } \\
\text { foamed with } \\
\text { air) }\end{array}$ & Ulceration & $\begin{array}{l}\text { Healed with } \\
\text { conservative } \\
\text { treatment }\end{array}$ \\
\hline 5 & $\begin{array}{l}74 / \\
\text { female }\end{array}$ & HFVM & $\begin{array}{l}\text { Left ring } \\
\text { finger }\end{array}$ & $\begin{array}{l}\text { Angiography } \\
\text { and direct } \\
\text { injection } \\
\text { EST ( } 2 \mathrm{ml} \text { of } \\
\text { ethanol, } \\
\text { and } 2 \mathrm{ml} \text { of } \\
\text { STS } 3 \% \\
\text { foamed with } \\
\text { air) }\end{array}$ & Ulceration & $\begin{array}{l}\text { Healed with } \\
\text { conservative } \\
\text { treatment }\end{array}$ \\
\hline
\end{tabular}




\begin{tabular}{|c|c|c|c|c|c|c|}
\hline 6 & $\begin{array}{l}19 / \\
\text { female }\end{array}$ & LFVM & $\begin{array}{l}\text { Palm of } \\
\text { left hand }\end{array}$ & $\begin{array}{l}\text { Direct } \\
\text { injection } \\
\text { EST ( } 12 \mathrm{ml} \\
\text { STS } \\
3 \% \text { foamed } \\
\text { with air) }\end{array}$ & $\begin{array}{l}\text { Hand } \\
\text { contracture }\end{array}$ & $\begin{array}{l}\text { Elevation and } \\
\text { surgical } \\
\text { tendon } \\
\text { release with } \\
\text { good result }\end{array}$ \\
\hline 7 & $\begin{array}{l}20 / \\
\text { male }\end{array}$ & LFVM & $\begin{array}{l}\text { Dorsum } \\
\text { of right } \\
\text { hand }\end{array}$ & $\begin{array}{l}\text { Direct } \\
\text { injection } \\
\text { EST (STS } \\
3 \% \text { foamed } \\
\text { with air) }\end{array}$ & $\begin{array}{l}\text { Ulceration } \\
\text { (Figure 2) }\end{array}$ & $\begin{array}{l}\text { Healed with } \\
\text { conservative } \\
\text { treatment }\end{array}$ \\
\hline 8 & $\begin{array}{l}32 / \\
\text { male }\end{array}$ & LFVM & $\begin{array}{l}\text { Right } \\
\text { upper } \\
\text { arm }\end{array}$ & $\begin{array}{l}\text { Direct } \\
\text { injection } \\
\text { EST ( } 3 \mathrm{ml} \text { of } \\
\text { ethanol) }\end{array}$ & $\begin{array}{l}\text { Median nerve } \\
\text { damage. } \\
\text { Profound } \\
\text { wrist drop }\end{array}$ & $\begin{array}{l}\text { Nerve } \\
\text { grafting and } \\
\text { hand therapy. } \\
\text { Currently on- } \\
\text { going } \\
\text { neurology } \\
\text { involvement }\end{array}$ \\
\hline 9 & $\begin{array}{l}47 / \\
\text { female }\end{array}$ & LFVM & $\begin{array}{l}\text { Right } \\
\text { ring } \\
\text { finger }\end{array}$ & $\begin{array}{l}\text { Direct } \\
\text { injection } \\
\text { EST }(3 \mathrm{ml} \text { of } \\
\text { STS 3\% } \\
\text { foamed with }\end{array}$ & Ulceration & $\begin{array}{l}\text { Healed with } \\
\text { conservative } \\
\text { treatment }\end{array}$ \\
\hline
\end{tabular}




\begin{tabular}{|l|l|l|l|l|l|l|}
\hline 10 & $26 /$ & LFVM & Left wrist & Direct & Ulceration & Healed with \\
\hline & female & & and & injection & & conservative \\
& & & thumb & EST (4 ml of & & treatment \\
& & & & STS 3\% & & \\
& & & & foamed with & & \\
\hline
\end{tabular}


Table 43 . Patients with major complications following embolo-sclerotherapy of lower extremity vascular malformations. EST: embolo-sclerotherapy, HFVM: high-flow vascular malformation, LFVM: low-flow vascular malformation, STS: sodium tetradecyl sulphate

\begin{tabular}{|c|c|c|c|c|c|c|}
\hline Patient & $\begin{array}{l}\text { Age } \\
\text { (years) } \\
\text { / } \\
\text { gender }\end{array}$ & $\begin{array}{l}\text { Type of } \\
\text { vascular } \\
\text { malformation }\end{array}$ & Anatomy & Procedure & Complication & $\begin{array}{l}\text { Treatment } \\
\text { and outcome }\end{array}$ \\
\hline 1 & $\begin{array}{l}27 / \\
\text { male }\end{array}$ & HFVM & $\begin{array}{l}\text { Right } \\
\text { lower leg }\end{array}$ & $\begin{array}{l}\text { Angiography } \\
\text { and direct } \\
\text { injection } \\
\text { EST (STS } \\
3 \% \text { foamed } \\
\text { with air) }\end{array}$ & Cellulitis & $\begin{array}{l}\text { Resolved with } \\
\text { antibiotics }\end{array}$ \\
\hline 2 & $\begin{array}{l}27 / \\
\text { female }\end{array}$ & LFVM & $\begin{array}{l}\text { Right } \\
\text { foot }\end{array}$ & $\begin{array}{l}\text { Direct } \\
\text { injection } \\
\text { EST }(6 \mathrm{ml} \text { of } \\
\text { STS } 3 \% \\
\text { foamed with } \\
\text { air) }\end{array}$ & $\begin{array}{l}\text { Ulceration } \\
\text { (Figure 3) }\end{array}$ & $\begin{array}{l}\text { Resolved with } \\
\text { conservative } \\
\text { management }\end{array}$ \\
\hline 3 & $\begin{array}{l}18 / \\
\text { female }\end{array}$ & LFVM & $\begin{array}{l}\text { Right } \\
\text { heel }\end{array}$ & $\begin{array}{l}\text { Direct } \\
\text { injection } \\
\text { EST }(6 \mathrm{ml} \text { of }\end{array}$ & Ulceration & $\begin{array}{l}\text { Resolved with } \\
\text { conservative } \\
\text { management }\end{array}$ \\
\hline
\end{tabular}




\begin{tabular}{|c|c|c|c|c|c|c|}
\hline & & & & $\begin{array}{l}\text { STS 3\% } \\
\text { foamed with } \\
\text { air) }\end{array}$ & & \\
\hline 4 & $\begin{array}{l}27 / \\
\text { male }\end{array}$ & LFVM & $\begin{array}{l}\text { Left } \\
\text { lower leg }\end{array}$ & $\begin{array}{l}\text { Direct } \\
\text { injection } \\
\text { EST ( } 5 \mathrm{ml} \text { of } \\
\text { ethanol) }\end{array}$ & Cellulitis & $\begin{array}{l}\text { Resolved with } \\
\text { antibiotics }\end{array}$ \\
\hline 5 & $\begin{array}{l}22 / \\
\text { male }\end{array}$ & LFVM & $\begin{array}{l}\text { Left } \\
\text { lower leg }\end{array}$ & $\begin{array}{l}\text { Direct } \\
\text { injection } \\
\text { EST ( } 6 \mathrm{ml} \text { of } \\
\text { STS 3\% } \\
\text { foamed with } \\
\text { air) }\end{array}$ & $\begin{array}{l}\text { Deep vein } \\
\text { thrombosis }\end{array}$ & $\begin{array}{l}\text { A period of } \\
\text { anticoagulation }\end{array}$ \\
\hline
\end{tabular}




\section{Legends for figures}

Figure 1. Angiogram and photographs of ischemic and gangrenous right distal index and little finger requiring amputation in a patient who had embolo-sclerotherapy of high-flow vascular malformation of the hand.

Figure 2. Photographs of skin ulceration of the dorsum of the right hand of a patient who had embolo-sclerotherapy of low-flow vascular malformation of the hand.

Figure 3. Photograph of skin ulceration with blistering of a patient who had embolosclerotherapy of low-flow vascular malformation of the foot. 


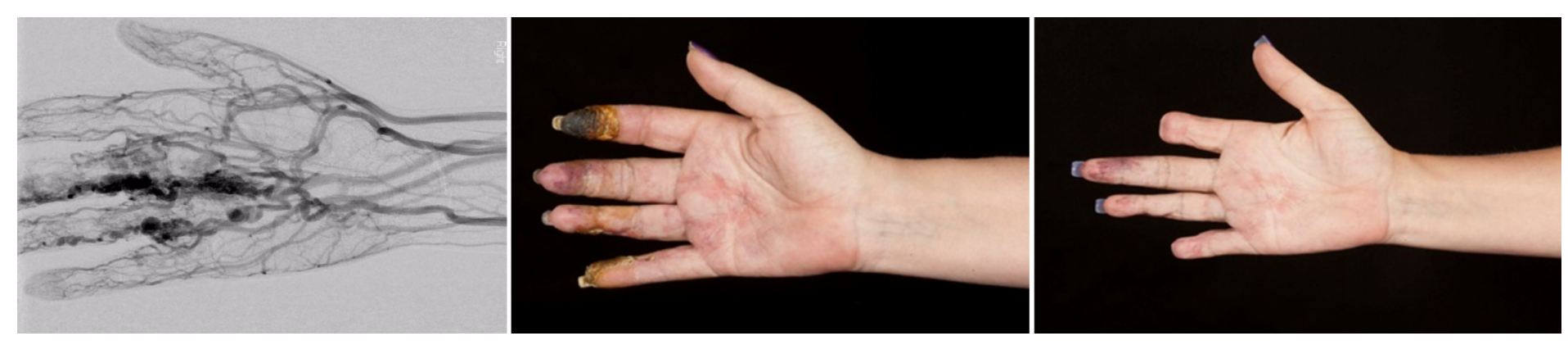




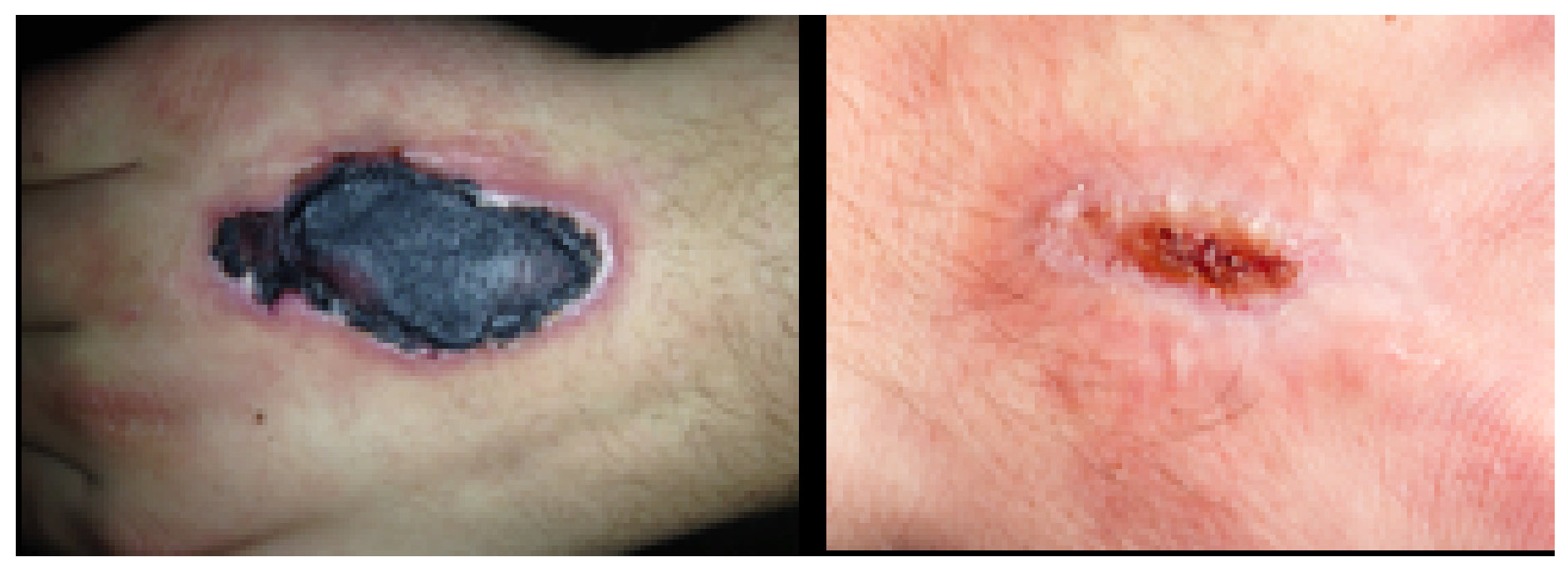




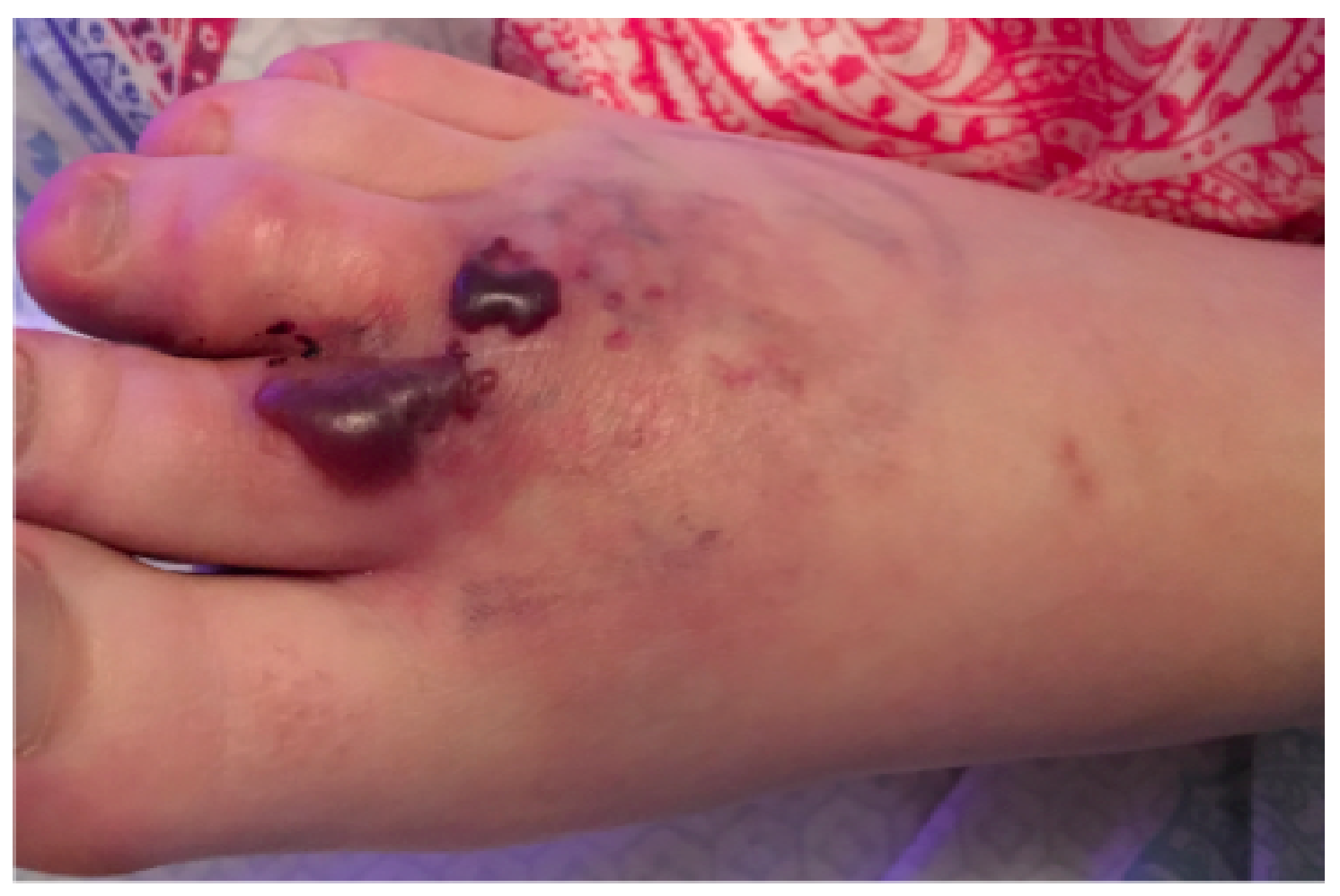

Confidential Material 